\begin{tabular}{l}
$\begin{array}{c}\text { Yanbu Journal } \\
\text { of }\end{array}$ \\
$\begin{array}{l}\text { Engineering } \\
\text { and Science }\end{array}$ \\
\hline \hline ISSN: $1658-5321$
\end{tabular}$\quad$ Vol. 15, December $2017(1438 \mathrm{H})$

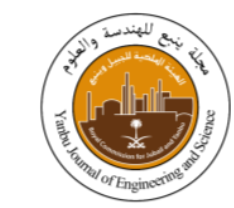

\title{
PREPARATION AND CHARACTERIZATION OF NANO-ACTIVATED CARBON FROM AGRICULTURAL WASTE FOR WASTEWATER TREATMENT: A REVIEW
}

\author{
Ebrahiem E. Ebrahiem ${ }^{1}$, Nabila Shehata $^{2}$, Hamdy F. M. Mohamed ${ }^{2}$, Taha L. Farag ${ }^{3}$, Gaber S. AbdelGhany ${ }^{2}$ \\ ${ }^{1}$ Chemical Engineering Department, Faculty of Engineering, Minia University, Minia, Egypt \\ ${ }^{2}$ Faculty of Post-Graduate Studies for Advance Science, Beni-Suef University, Egypt. \\ ${ }^{3}$ Chemical Engineering, Faculty of Engineering, Port Said University, Egypt. \\ E-mail:Ebrahiem59@yahoo.com
}

\begin{abstract}
Activated carbon generated from cellulosic material such as agriculture wastes received great attention. The synthesis of activated carbon from biomass by physical and chemical activation methods and its classification were reviewed. The effect of carbonization parameters (chemicals activation reagent, temperature) on surface area and pore volume of activated carbon was discussed. Nano-carbon forms and applications are considered. Also the effect of milling on carbon structures was discussed.
\end{abstract}

Keywords: Activated carbon, Agriculture waste, Chemical activation, Application of Nanocarbon.

\section{INTRODUCTION}

Many types of toxic substances are present in wastewater from different industries such as fabric, paper, construction materials, leather, plastic, cosmetic and printing industries [1]. The rapid pace of industrialization and urbanization activities has become an important environmental concern because of the disposal of wastes generated to the ecosystem. Heavy elements have specific gravity greater than 4 [2]. The effects of these pollutants on the environment and humans are dangerous. Searching for efficient methods to remove these pollutants is necessary for both human's health and aquatic organisms [3]. Many types of adsorbents such as carbon filters, silt materials, biomaterials, nanoparticles, fly ash and leaves have been widely used to remove harmful pollutant from aqueous stream [4, 5-6]. Oxidation using safe oxidizing agents such as ozone and adsorption to activated carbon (AC) are the most used treatment to remove contaminants [7]. One future apect of nanotechnology depends on the ability to produce new nanomaterial that has structural and functional features that are effective for this purpose [8]. The unique magnetic, surface chemistry, optical characteristics and the properties of corresponding bulk materials of nanomaterials make them desirable for different applications including adsorption, electronic sensing, medical applications, and drug delivery [9]. Mesoporous carbon has been major research topic because of its distinctive competent properties such as low density, high surface area, large pore size, electrophoresis, thermal conductivity, good 
mechanical and chemical stability [10]. Improved AC properties such as increased surface area, pore size distribution and functional surface groups can be obtained from various precursors with high carbon content such as agriculture wastes [11]. In general, the characteristics of the final AC product depend primarily on the nature of the raw materials containing the carbon and also, the mechanical and thermal processing for carbon production [12]. One of the main interests that has recently emerged is the production of carbon using biological waste materials that not only reduces the impact of the environment, but can also be more effective than available polychlorinated naphthalene [13]. The advantage of vital clean materials such as rice husk, wheat straw, seaweed, wood pulp, tea waste, maize cob, sugar cane, sawdust, wool, olive shells, almond shells, cactus leaves, banana and orange peel, cellulose, lignin and hemicellulose compared with fossil fuels. On the other hand, biomass wastes have harmful effect on the ecosystem [14-16]. The use of rice husk not only has benefits of valuable carbon production but also reduces the problems of wastes and pollution [17]. Many investigations show that pure amorphous carbon can be prepared from cheap rice wastes $[18,19]$. In addition, the presence of surface functional groups on carbon materials has a significant role in improving adsorption performance and also in the preparation of highly stable AC [20]. Because of their chemically inert nature, most carbon materials usually do not have the desired functional groups on their surfaces. So additional surface modifications are made; for example oxidation treatment is applied to provide functional oxygen groups $[21,22]$. Powder AC is often seen as an alternative to the current advanced wastewater treatment. The nature of AC surfaces, particularly active carbon nanotubes, has made the absorption of heavy metals from industrial wastewater applicable. Activated Carbon Fiber (ACF) is an amorphous carbon fiber with high surface area and functional groups used in the industrial processes [23, 24]. Activated carbon fiber has structure with many small porous opening and large surface area; which makes it denser, faster and more efficient than powder AC [25]. Several reports have emerged on the development of low-cost AC from easily available agricultural residues [26- 28]. Furthermore, the mechanical and thermal treatment of these waste materials is carried out through the process of carbonization and grinding, in order to achieve AC in nano-scale structure and to have aloft adsorption properties. The pore size of the AC has been classified into three types, According to International Union of Pure and Applied Chemistry (IUPAC) [29].

1. Micropore (pore size $<2 \mathrm{~nm})-(8-$ $100 \AA$ A) [30, 31] which may be divided into ultra micropore $(<0.5$ $\mathrm{nm})$ and super micropore (1-2nm) [32]. The micropore size distribution determined by nonlocal density functional theory (NLDFT), $\mathrm{N}_{2}$ adsorption isotherms, t-plot method, Dubinin-Raduskevich (DR) method, the alpha method or immersion micro calorimeter of liquids.

2. Mesopore $(2 \mathrm{~nm}<$ pore size $<50 \mathrm{~nm})$ - $(100-500$ A) $[30,31]$. The mesopore volume $\left(\mathrm{V}_{\mathrm{me}}\right)$ is calculated as the difference between total pore volume $\left(\mathrm{V}_{\mathrm{T}}\right)$ and micropore volume $\left(\mathrm{V}_{\mathrm{mi}}\right)$.

3. Macropore (pore size> $50 \mathrm{~nm}$ ) $(500-20,000 \quad \AA) \quad[30, \quad 31]$. 
Incorporation of macropores in mesoporous materials combines benefits from both of them.

The pore size distribution of activated carbon and pore structure depends originally on the nature of the starting material [33, 34]. The distribution of pore size of $A C$ depends mainly on the degree of thermal treatment and the catalyst used. Shapes and sizes depend on the type of activation [34]. The resulting porosity is due to increase the burning of the carbon [35]. Raw materials and the state of carbonization and activation are the most important factors affecting on porosity types and their distribution of activated carbon prepared $[36,37]$.

\section{AGRICULTURAL WASTE MATERIAL AS AC PRECURSORS}

Activated carbon can be generated naturally from carbonaceous wastes [38]. Characteristics of starting material, its property and the used activation process also may influence the properties and structure of the final AC product [39-40] and qualities, as well as the activation procedures [41]. Abandoned agricultural wastes are of the best potential sources used as alternatives to high-cost capacitors for the removal of wastewater pollutants [42]. Wastes such as agriculture wastes are the main sources of biomass; which is chemically composed of carbon, hydrogen, oxygen, nitrogen and traces of chlorine and sulfur in different functional groups forms [43]. Various biomass materials have been developed from agricultural wastes such as wheat straw, rice husk, seaweed, wood bark, tea waste, corn flour, cane cub, sawdust, wool, sugarcane bagasse, olive cake, pine needles, almond shells, cactus leaves, bananas, orange peel, etc. $[44,45]$. All materials have their own advantages and limitations, so there is still a need to improve the properties of resulted adsorbents. The conversion of solid wastes such as biomass to activated carbon to treat polluted water will add economic value by providing an alternative to activated carbon with low cost and better characteristics [17, 46]. Any cheap wastes with low inorganic content and high carbon content can be used for producing the AC.

\section{PREPARATION OF ACTIVATED CARBON}

The preparation of AC commonly consists of carbonization and activation that can be done either merged in a single stage process or separately in two-stage process. The carbonization of the precursors takes place at high temperature in the absence of oxygen. Thermal decomposition can convert materials containing carbon into activated carbon [43]. Highly porous AC can be produced using three processes: chemical, physical and physico-chemical activation [46].

\subsection{Physical ACtivation}

The physical activation consists of carbonaceous material carbonization followed by activation of the resulting char at high temperature in the presence of oxidizing gases such as carbon dioxide, steam, air or their mixtures. Higher temperatures improve the diameter of the pores, where as the pore volume increases substantially [47]. Physical activation using steam as oxidizing gas is the best potential for producing ACs with good pore ratio and high surface area [48]. The carbonization occurs as pyrolysis of the precursors at an appropriate temperature $\left(500-1000^{\circ} \mathrm{C}\right)$ in an inert atmosphere gas in order to eliminate hydrogen and oxygen [49]. Temperatures $\left(400: 600^{\circ} \mathrm{C}\right)$ are required before partial gasification to develop the porosity at higher 
temperature [23]. The thermal activation occurs at a temperature higher than the temperature of the pyrolysis or at the same temperature of pyrolysis in the presence of oxidant gas [50]. The produced activated carbon is affected by the activation agent, the activation method, and other factors parameters such as pressure, flow rate of oxidizing gas and heating rate, etc. [51]. Long pyrolysis period, high temperature, and loss of volatile components increase the ash content [52].

\subsection{ChEMiCAL ACTIVATION}

The chemical activation has more advantages than physical activation, including higher yield, shorter time, lower temperature, larger surface area [53] and greater micro-pore structure [54]. Chemical activation is carried out in a single step, combining activation and carbonization [55]. The chemical activation involves impregnation the carbonaceous material with a chemical oxidizing agent such as $\mathrm{H} 2 \mathrm{SO} 4$ [47], $\mathrm{ZnCl} 2$ [56, 57], $\mathrm{KOH}$ [58], H3PO4 [59, 60], K2CO3 [61]. The porosity of $\mathrm{ACs}$ is formed by dehydration reactions of activating reagent [23]. This activation requires a relatively low temperature of range from 300 to $800{ }^{\circ} \mathrm{C}$ [29] which is lower than physical activation temperature [62]. Activated carbons characteristics produced from various agricultural precursors by physical and chemical activation are present in Tables 1 and 2 , respectively.

TABLE 1: CHARACTERISTICS OF ACS FROM VARIOUS AGRICULTURAL MATERIALS USING PHYSICAL ACTIVATION

\begin{tabular}{|c|c|c|c|c|c|c|}
\hline Precursor & Activation Agent & $S_{\mathrm{BET}}\left(\mathrm{m}^{2} / \mathrm{g}\right)$ & $\mathrm{Vt}\left(\mathrm{cm}^{3} / \mathrm{g}\right)$ & $V_{m i}\left(\mathrm{~cm}^{3} / \mathrm{g}\right)$ & $V_{m e}\left(\mathrm{~cm}^{3} / \mathrm{g}\right)$ & Ref. \\
\hline Corn shell & $\begin{array}{c}\mathrm{CO}_{2} \& \\
\mathrm{H}_{2} \mathrm{O}\end{array}$ & 1779 & 0.927 & - & - & {$[47]$} \\
\hline Olive-tree wood & Air & 481 & - & 0.226 & 0.046 & [48] \\
\hline Sawdust & $\mathrm{N}_{2}$ flow & 515.4 & 0.208 & 0.195 & 0.013 & [51] \\
\hline Sawdust & Under $\mathrm{CO}_{2}$ flow & 1003 & 0.538 & 0.462 & 0.076 & [51] \\
\hline $\begin{array}{l}\text { Corrugated } \\
\text { cardboard }\end{array}$ & Stream of argon & 268 & 0.18 & 0.12 & - & [52] \\
\hline \multirow{2}{*}{ Waste tea } & $\mathrm{H}_{3} \mathrm{PO}_{4}$ & 1327 & 1.142 & 0.2778 & 0.8651 & \multirow{2}{*}{54} \\
\hline & $\mathrm{K}_{2} \mathrm{CO}_{3}$ & 1125 & 0.592 & 0.5420 & 0.050 & \\
\hline Bamboo waste & Steam flush & 363 & 0.15 & 0.13 & - & {$[63]$} \\
\hline \multirow{2}{*}{ Bagasse } & $\mathrm{CO}_{2}$ & 1433 & 0.91 & - & - & [64] \\
\hline & Steam & 1579 & 1.1 & - & - & [65] \\
\hline Date stones & $\mathrm{CO}_{2}$ & 604 & 0.34 & 0.29 & - & {$[66]$} \\
\hline Palm shell & $\mathrm{CO}_{2}$ & 984 & 0.76 & & - & {$[67]$} \\
\hline Coconut shell & Steam & 1054 & 0.517 & 0.092 & - & {$[68]$} \\
\hline $\begin{array}{c}\text { Peach and apricot } \\
\text { stone }\end{array}$ & Steam & 1150 & 0.44 & - & - & [69] \\
\hline Moso bamboo & Steam & 1135 & 0.718 & 0.521 & - & [70] \\
\hline
\end{tabular}


TABLE 2: CHARACTERISTICS OF ACS FROM VARIOUS AGRICULTURAL MATERIALS USING CHEMICAL ACTIVATION

\begin{tabular}{|c|c|c|c|c|c|c|}
\hline Precursor & Activation Agent & $\mathrm{S}_{\mathrm{BET}}\left(\mathrm{m}^{2} / \mathrm{g}\right)$ & $\mathrm{Vt}\left(\mathrm{cm}^{3} / \mathrm{g}\right)$ & $V_{m i}\left(\mathrm{~cm}^{3} / \mathrm{g}\right)$ & $V_{\text {me }}\left(\mathrm{cm}^{3} / \mathrm{g}\right)$ & Ref. \\
\hline $\begin{array}{c}\text { Silkworm } \\
\text { cocoon waste }\end{array}$ & $\left(\mathrm{NH}_{4}\right)_{2} \mathrm{HPO}_{4} \mathrm{KOH}$ & 2797.30 & 1.735 & 1.409 & - & [23] \\
\hline \multirow{4}{*}{ Crab shell } & $\mathrm{KOH}$ & 2197 & 1.192 & 0.832 & - & \multirow{4}{*}{ [53] } \\
\hline & $\mathrm{NaOH}$ & 2126 & 1.321 & 0.655 & - & \\
\hline & $\mathrm{H}_{3} \mathrm{PO}_{4}$ & 300 & 0.208 & 0.118 & & \\
\hline & $\mathrm{H}_{4} \mathrm{P}_{2} \mathrm{O}_{7}$ & 309 & 0.268 & 0.080 & & \\
\hline $\begin{array}{c}\text { Pomegranate } \\
\text { seeds }\end{array}$ & $\mathrm{ZnCl}_{2}$ & 978.8 & 0.563 & 0.283 & 0.280 & [56] \\
\hline Cassava peel & $\mathrm{KOH}$ & 1378 & 0.520 & & & [58] \\
\hline Moso bamboo & $\mathrm{KOH}$ & 2527 & 1.52 & 0.962 & & {$[70]$} \\
\hline Potato residue & $\begin{array}{l}\mathrm{ZnCl} 2 \text { solutions } \\
\quad(50 \text { wt. } \%)\end{array}$ & 1357 & 1.065 & 0.083 & 0.982 & [71] \\
\hline Grape waste & $\mathrm{ZnCl}_{2}$ & 1455 & 2.318 & & - & [72] \\
\hline $\begin{array}{l}\text { Tomato solid } \\
\text { waste }\end{array}$ & $\mathrm{ZnCl}_{2}$ & 1093 & 1.569 & 0.129 & 1.440 & [73] \\
\hline \multirow{2}{*}{ Rubber tires } & $\mathrm{NaOH}$ & 369.27 & 0.69 & - & - & \multirow{2}{*}{ [74] } \\
\hline & $\mathrm{HNO}_{3}$ & 473.35 & 0.70 & - & - & \\
\hline Wood & $\mathrm{H}_{3} \mathrm{PO}_{4}$ & 1708 & & - & - & [75] \\
\hline Rice husk & $\mathrm{KOH}$ & 3263 & 1.772 & 1.132 & 0.640 & [76] \\
\hline $\begin{array}{c}\text { Chinese } \\
\text { sargassum }\end{array}$ & $\mathrm{H}_{3} \mathrm{PO}_{4}$ & 1337.0 & 0.8 & - & - & {$[77]$} \\
\hline Plum stones & $\mathrm{KOH}$ & 3228 & 1.61 & 1.57 & - & {$[78]$} \\
\hline Grape seeds & $\mathrm{ZnCl}_{2}$ & 497 & 0.12 & - & - & [79] \\
\hline Almond shells & $\mathrm{ZnCl}_{2}$ & 998 & 0.40 & - & - & [79] \\
\hline Apricot stones & $\mathrm{ZnCl}_{2}$ & 1190 & 0.50 & - & - & [79] \\
\hline Papaya peel & Phosphoric acid & 15.26 & & - & - & [80] \\
\hline $\begin{array}{c}\text { Cocoa pod } \\
\text { husk }\end{array}$ & $\mathrm{KOH}$ & 490 & 0.24 & - & - & [81] \\
\hline $\begin{array}{c}\text { Sugarcane } \\
\text { bagasse }\end{array}$ & $\mathrm{ZnCl}_{2}$ & 1788 & 1.74 & 0.19 & 1.55 & [82] \\
\hline Coconut shells & $\mathrm{ZnCl}_{2}$ & 2114 & 1.307 & 1.142 & - & [83] \\
\hline $\begin{array}{c}\text { Camellia } \\
\text { oleiferaargan }\end{array}$ & $\mathrm{ZnCl}_{2}$ & 2080 & 1.18 & 0.12 & 1.06 & [84] \\
\hline $\begin{array}{l}\text { Sunflower seed } \\
\text { shell waste }\end{array}$ & $\mathrm{KOH}$ & 1235 & 0.67 & 0.59 & 0.08 & [85] \\
\hline
\end{tabular}

\section{EFFECT OF OPERATIONAL PARAMETERS ON THE RESULTED $\mathrm{AC}$}

Characterization of activated carbon is done by various instruments such as scanning electron microscope (SEM), x-ray diffraction (XRD), $\quad \mathrm{N}_{2}$ adsorption/desorption and Fourier transform infrared spectroscopy (FTIR). These techniques are used to determine surface area, pore size distribution, pore volume and function groups structure which helps choose the best conditions for producing $\mathrm{AC}$ at its best properties.

\subsection{EFFECT OF CARbonization TEMPERATURE (CT) ON SURFACE AREA AND PORE VOLUME}

One of the most important synthesis factors affecting the textural properties of the $\mathrm{AC}$ is carbonization temperature (CT). The $\mathrm{S}_{\mathrm{BET}}$, $\mathrm{V}_{\mathrm{T}}, \mathrm{V}_{\text {mes }}(\%)$ and $\mathrm{D}_{\mathrm{p}}(\mathrm{nm})$ values are increased as CT increased, due to the creation of new pores [72]. When the raw materials were activated at low $\mathrm{CT}$, predominantly micro porous was observed, while meso porous were formed gradually with CT increasing [63]. Zhang et al. [86] studied the effects of 
the CT on the physical properties of the AC generated from waste potato. It was observed that $S_{\mathrm{BET}}$ and $\mathrm{V}_{\mathrm{T}}$ increased as CT increased from 400 to $600{ }^{\circ} \mathrm{C}$ and then gradually decreased when CT increased from 600 to $800{ }^{\circ} \mathrm{C}$. The surface area and pore volume decreased because of heat shrinkage [87]. Also, carbonization temperature plays an important role in the AC production. At CT range of 450 to $550{ }^{\circ} \mathrm{C}$, the loss of weight is primarily high because the amount of volatiles released as well as the loss of moisture. The yield of the $\mathrm{AC}$ at temperatures more than $650{ }^{\circ} \mathrm{C}$ is less than fixed carbon in initial precursor. However, increasing the CT from 450 to $750{ }^{\circ} \mathrm{C}$ results in creation of new pores, due to increasing the evolution of volatile matters [58]. The effect of the carbonization temperature on the specific capacitance of $\mathrm{RH}$ carbon was investigated as shown in Figure 1. The temperature was increased from 500 to $900{ }^{\circ} \mathrm{C}$, keeping the activation time and $\mathrm{KOH}$-to-RHC ratio constant at 1 $h$ and 3:1. The highest specific surface area and specific capacitance $2,367 \mathrm{~m}^{2} \mathrm{~g}^{-1}$ and $288 \mathrm{~F} \mathrm{~g}^{-1}$, respectively were achieved at CT $700{ }^{\circ} \mathrm{C}$. It was found that as CT was increased, the activation reaction increased and caused the formation of much more pores and specific surface area. When CT surpassed $700{ }^{\circ} \mathrm{C}$, the activation reaction became so fast, resulting in over-etching and lower specific surface area was obtained. When the CT reached $900{ }^{\circ} \mathrm{C}$, the specific surface area decreased to $2,031 \mathrm{~m}^{2} \mathrm{~g}^{-1}$ [76]. The pore volumes of the $\mathrm{AC}$ generated from lignin by chemical activation using $\mathrm{ZnCl}_{2}$ and $\mathrm{H}_{3} \mathrm{PO}_{4}$ as oxidizing agent were studied. The activation increased with increase in temperature over the range 500 to $600{ }^{\circ} \mathrm{C}$, and decreased with increase temperature over the range of 600 to $900{ }^{\circ} \mathrm{C}$.
When the temperatures were higher than $600{ }^{\circ} \mathrm{C}$, the surface areas of $\mathrm{AC}$ decreased and the carbon structure shrinked. The pore volumes of the AC produced using alkali metals compound generally increase with CT up to about $800{ }^{\circ} \mathrm{C}$. This referred to the pores enlarge up to this temperature. When the temperature is higher thsn $800{ }^{\circ} \mathrm{C}$, the excess enlargement induces combination of pores, resulting in a decrease of surface area and micropore volume and an increase in mesopores, [87].

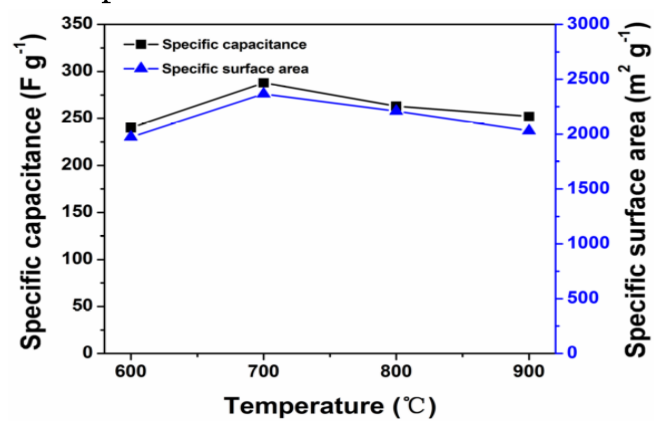

Fig.1. Effect of CT on the specific capacitances and specific surface area of rice husk-AC [76].

\subsection{EFFECT OF CHEMICAL ACTIVATION REAGENTS ON SURFACE AREA AND PORE VOLUME}

Cross-linking structures in the form of phosphate ester can be developed by activation with $\mathrm{H}_{3} \mathrm{PO}_{4}$ which is directly related to porosity improvement. These cross links reach a limit of thermal stability when the temperature maintained at 450$500{ }^{\circ} \mathrm{C}$. The higher temperatures cause a reduction of cross-links and minimize the development of porosity [29]. AC was produced from pomegranate seeds using $\mathrm{ZnCl}_{2}$ at 600 and $800{ }^{\circ} \mathrm{C}$ as shown in Figure 2. The recovery was found to be from 74.43 to 81.24 wt.\%. The final yield of $\mathrm{AC}$ was affected by the concentration of zinc chloride. The benefit of $\mathrm{ZnCl}_{2}$ was inhibition of tar formation and dehydration that influenced pyrolysis decomposition [56]. Although, AC was prepared from grape industry waste without any activating agent, 

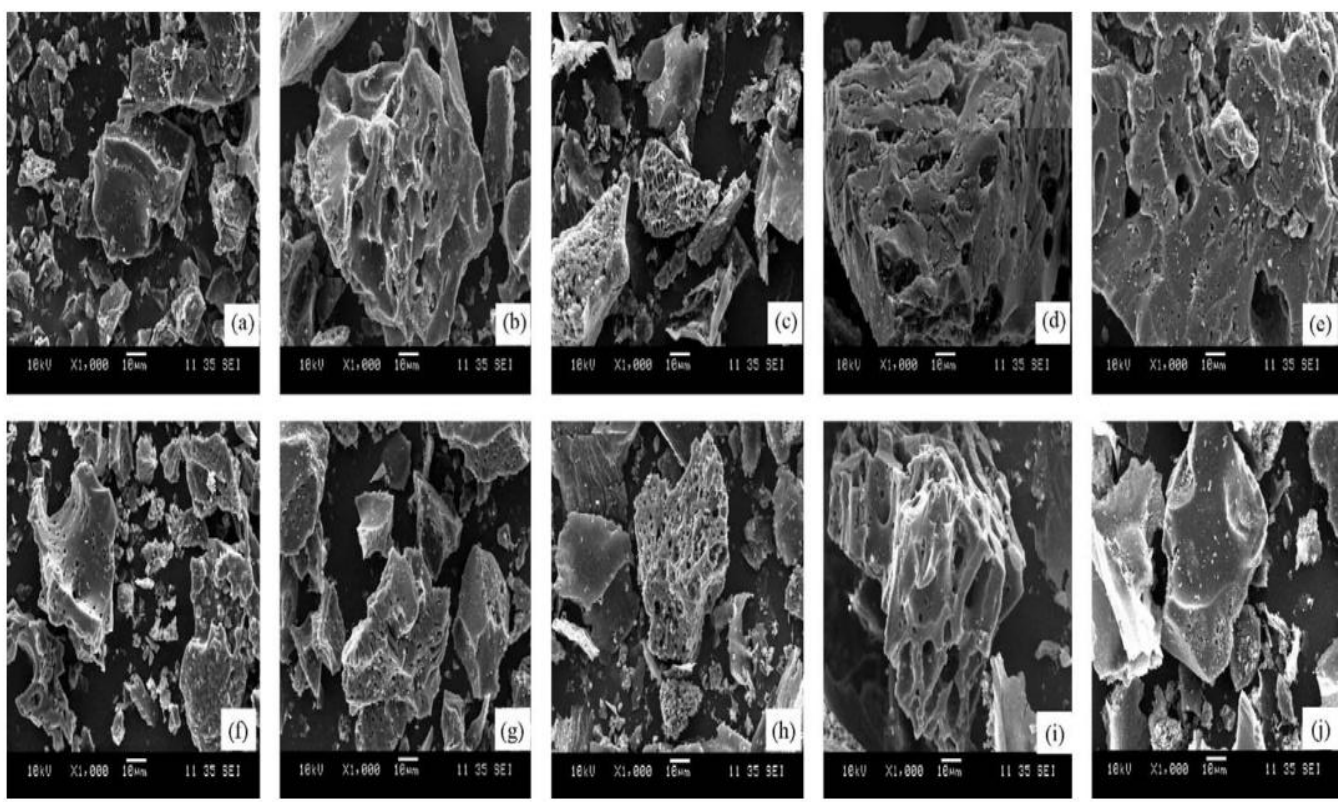

Fig.2. SEM images of $\mathrm{AC}$ produced from pomegranate by $\mathrm{ZnCl}_{2}$ activation at 600 and $800{ }^{\circ} \mathrm{C}$ [56].

the produced $A C$ had very low $S_{B E T}, V_{T}, V_{\text {mic }}$, $\mathrm{V}_{\text {mes }}$ and $\mathrm{D}_{\mathrm{p}}(\mathrm{nm})$. In case of activation using $\mathrm{ZnCl}_{2}$, the resulted $\mathrm{AC}$ had high porosity and surface area due to increase of the raw material degradation. $\mathrm{ZnCl}_{2}$ causes dehydration of the raw material, burning of the carbon skeleton and creates new porous structure during the carbonization [72]. However, the impregnation of the precursors with alkaline hydroxides agent such as $\left(\mathrm{NaO}_{\mathrm{H}}\right.$ and $\left.\mathrm{KOH}\right)$ generated $\mathrm{AC}$ with higher specific surface area [59]. Waste tire also have been used for AC preparation using acid and base activation at different temperatures. Saleh et al. observed that AC treated with acids had better properties than that treated with bases. The pore volumes and surface area of $\mathrm{AC}$ activated with $\mathrm{HNO}_{3}$ at $90^{\circ} \mathrm{C}$ were 0.70 $\mathrm{cm}^{3} / \mathrm{g}$ and $473.35 \mathrm{~m}^{2} / \mathrm{g}$, respectively, which were higher than that activated with $\mathrm{NaO}_{\mathrm{H}}$ at $60{ }^{\circ} \mathrm{C}\left(\mathrm{V}_{\mathrm{p}}, 0.69 \mathrm{~cm}^{3} / \mathrm{g}, \mathrm{S}_{\mathrm{BET}}, 369 \mathrm{~m}^{2} / \mathrm{g}\right)$ [74]. Activation for long time may have a negative effect on the AC generated from silkworm cocoons by $\mathrm{KOH}$ activation. It was observed that $S_{\mathrm{BET}}$ decreased from 2797 to $1163 \mathrm{~m}^{2} / \mathrm{g}$ and pore volume decreased from 82.34 to $75.18 \%$ when increasing activation time from 1 to $4 \mathrm{~h}$. This may be attributed to the reduction of $\mathrm{KOH}$ to metallic potassium, as $\mathrm{KOH}$ may be associated with the gasification reaction. In addition, pretreatment with $\left(\mathrm{NH}_{4}\right)_{2} \mathrm{HPO}_{4}$ increases the carbon yield [23]. Gergova et al. [50] prepared AC with high porosity from date stones by pyrolysis using $\left(\mathrm{H}_{2} \mathrm{O}\right)$ as oxidant gas. This high porosity was due to the production of new pores in the carbon structure resulted from the elimination of volatile matters and recycling of the carbon atoms in the glycoside rings. Activated carbon of high surface area was produced from crab shell using $\mathrm{KOH}$ and $\mathrm{NaO}_{\mathrm{H}}$ activation. The produced $\mathrm{AC}$ was effective for removal of contaminants and pollutants from wastewater stream [53].

\subsection{EFFECT OF MILLING ON NAC STRUCTURES}

Applying of ball milling is common to materials which need to be transformed to nano-size. Ball milling used for the production of single-wall CNTs to produce highly curved nanostructures. Morphology of cup-stacked CNTs affected by ball 
milling. High energy milling also used to reduce the length of the single-walled CNTs, to form nanobarrels and to shorten the nanotubes, and to increase the number of consenting active sites and the anisotropic characteristic at both ends [88, 89]. Highenergy ball milling decreases their particle sizes and increases the amount of amorphous carbon. Increasing the grinding time shortens the multi-wall CNTs entangling each other. Some multi-wall nanotubes are broken and subsequently their closed ends become opened during the milling. There are compatible conditions for modification the opened structure of multi-wall nanotubes. Ball milling is able to affect the morphology of particles and also introduces crystal defects and refines the microstructure. Ball milling is performed in atmosphere to produce samples reinforced with a presumably higher amount of in-situ reinforcement. Ball milling is also expected to destroy the outer surface of the ceramic shells and to disperse the oxide fragments in the metal matrix leading to dispersion hardening (in-situ reinforcement) the morphology of the as received powders is made up of quasi-spherical particles with diameter lower than $45 \mu \mathrm{m}$ [90].

\section{PREPARATION OF DIFFERENT TYPES OF NANO-CARBON}

Nano-AC appears after preparation in different forms such as carbon nano-spheres, carbon nano-tube and carbon nano-fiber depending on type of preparation method.

\subsection{Carbon Nano-Spheres (CNS)}

Nano-size spherical particles of $\mathrm{AC}$ are produced from raw Magahara coal by thermal and chemical activation process using $\mathrm{KOH}$ followed by carbonization at $600{ }^{\circ} \mathrm{C}$ for $90 \mathrm{~min}$. The nano-size spherical particles of pronounced porosity and series of irregular cavities distributed over the surface of the AC can be observed [86]. Carbon nano-spheres can be obtained by the pairing of pentagonal and heptagonal carbon rings, used in some specific applications. Bio-waste materials as a source of carbon containing materials have been used for preparation of CNS. The results showed wonderful particle size along with high zeta potential values. Quality and crystallographic properties were determined by TEM and XRD analyses. It was an easily CNS synthesis method using convenient and safety catalyst-free pyrolysis technique [91]. Shuo et al. [92] prepared CNS from potato starch with perfectly retaining of the original morphology. A destruction of the regular super molecular structure in the potato starch has been done during stabilization and carbonization. As stabilization was carried out intensively, the inter molecular cross-linking and rearrangement of porosity were the dominating parameters on the structural change. Meso-phase pitches were converted to carbon nanoparticle using hot injection method using oleic acid solution, $\mathrm{H}_{2} \mathrm{SO}_{4}$ as activation agent at $180{ }^{\circ} \mathrm{C}$. They are important synthesis conditions to produce carbon nano-structures with various morphologies [93]. It was more efficiently to produce uniform CNS when sucrose molten with $\mathrm{KOH}$ was used as precursor without any catalysts using hydrothermal route. A mono-disperse between 100-150 nm CNS was obtained [94]. Another agriculture waste, namely oil palm leaves has been used as a source of carbon to produce carbon nanoparticles. Ali et al. [13] generated porous carbon structure in Nano-scale in one step by pyrolysis in inert atmosphere $\left(\mathrm{N}_{2}\right)$. Firstly oil palm leaves were separated from a local oil palm and dried at $60{ }^{\circ} \mathrm{C}$ for 
$48 \mathrm{~h}$ to remove all the water content. Then, the dry oil palm leaves were crushed, grinded and sieved. Finally, the powder underwent pyrolysis in a furnace tube at 500 and $600^{\circ} \mathrm{C}$ for $2 \mathrm{~h}$ and cooled down to room temperature in $\mathrm{N}_{2}$ atmosphere to get the porous carbon nanoparticles. Irregular porous CNS has resulted, when adding of $\mathrm{Na}_{2} \mathrm{SnO}_{3}$ on corn porous starch as a precursor [95].Carbon nano spheres also have been produced from saturated hydrocarbons. A liquid hydrocarbon was introduced carefully into double furnace apparatus for the pyrolysis with the desired feed rate controlled by a pump at $250{ }^{\circ} \mathrm{C}$, resulting in $99 \%$ carbon as CNS $(1-5 \mathrm{~nm})$ [96].

\subsection{Carbon Nano-Tube (CNTS)}

Preparing CNTs has quickly improved every year, to synthesis large amount of sizecontrolled CNTs for commercial applications. CNTs are classified into two types: (1) multi-walled CNTs (MWCNTs) and (2) single-walled CNTs (SWCNTs) [97, 98]. Many methods were tried to get short and open ended CNTs. Examples of these methods are acid etching, scanning tunnelling microscope (STM) voltage, radiation treatment, ultrasonic treatment and ball milling. Among them, ball milling appears to be the easier process for cutting CNTs. ball milling is a reasonable method to crack and to open the closed ends of CNTs [99]. More recently, SWCNTs have been prepared based on the pyrolysis of hydrocarbon by catalytic chemical vapor deposition at relatively low temperatures [100]. Zhu et al. [101] prepared Multiwalled carbon nano tubes CNTs from bamboo plants using tube furnace. The bamboo plants were placed on an alumina substrate and then inserted into tube furnace to obtain bamboo charcoals, heated at temperatures between 1200 and $1500{ }^{\circ} \mathrm{C}$ and then passing through a bath of ethanol under flowing of Ar. Multi-walled CNTs have been synthesized from graphite by ball milling and annealing. Mechanical milling produces a disordered and nano-porous structure, which provides nanotube nucleation sites [102]. Immobilizing CNTs onto a carbon support was done to shuffle the unparalleled properties of CNTs with those of conventional $\mathrm{AC}$, and to maintain the chemical compatibility between these two phases of different dimensionality. A hierarchically carbon structure, consisting of CNFs supported on $\mathrm{AC}$, was successfully produced by CVD of $\mathrm{C}_{2} \mathrm{H}_{4}$ on an ACsupported iron catalyst. Agriculture-derived AC contains iron was directly used for synthesis $\mathrm{CNF}$ as a catalyst. The process involved preparation of $\mathrm{Fe}$ particles on the $\mathrm{AC}$ was circumvented and the overall process was simplified. Differing from other natural materials for CNT synthesis, AC may suffer gasification during CVD treatment at high temperatures in the presence of oxygen. The generation of CNFs on the AC was organized to be nonproportional to the amount of iron in the starting AC. The diameters of the CNFs were less than of $300 \mathrm{~nm}$, with a small number having diameters as large as $500 \mathrm{~nm}$ [103]. Natural resources such as stone garnet sand as a catalyst and support, and city gas based natural gas as the carbon source are efficient method and environmentally friendly for growing multi walled carbon nanotubes (MWCNTs). Garnet powder consists of $\mathrm{Fe}_{2} \mathrm{O}_{3}, \mathrm{FeO}, \mathrm{Al}_{2}$ $\mathrm{O}_{3}$, and $\mathrm{SiO}_{2}$, among other things. The air oxidation of the garnet sand $(-200 \mu \mathrm{m})$ at $1000^{\circ} \mathrm{C}$ for $6 \mathrm{~h}$ is a decisive step to enhance the production and growth rate of CNTs before introducing garnet powder into the 
reaction chamber. Gas for urban consumption was used as the carbon source. It contains propane, ethane, methane, dimethyl sulfide, n-butane, and isobutene as an additive so that the gas can be detected by smell [104]. Acetylene gas as a carbon source is used for producing MWCNTs by catalytic CVD method at $600-900{ }^{\circ} \mathrm{C}$ for $20 \mathrm{~min}$. Two different morphologies of MWCNTs synthesized well-aligned bundles and entangled aggregates [99]. Pierard et al. [88] synthesized SWNTs form methane by catalytic decomposition using Co supported on $\mathrm{MgO}$ as catalyst. Also decomposition of Acetylene for creating nano carbon structure using Kaolin supported Co catalyst has been investigated. $\mathrm{CNT}_{S}$ grown over the catalyst have diameter of $30-40 \mathrm{~nm}, 20 \mu \mathrm{m}$ in length. A mixture of carbon nanotubes and carbon spheres were obtained using ceramic plate as substrate [105]. Using acid-attapulgite as template and furfuryl alcohol as carbon source were investigated for synthesis the carbon nanotubes through a vapor deposition polymerization (VDP) method. Carbonized furfuryl alcohol-attapulgite in furnace under $\mathrm{N}_{2}$ atmosphere was tested [106]. Chen and Wang prepared MWCNTs using acetylene in hydrogen flow at $760{ }^{\circ} \mathrm{C}$ by chemical vapor deposition (CVD) and $\mathrm{Ni}-\mathrm{Fe}$ nanoparticles as catalysts. $\mathrm{N}_{2}$-BET method showed the specific surface area of MWCNTs to be $197 \mathrm{~m}^{2} \mathrm{~g}^{-1}$ [107].

\subsection{CARbON NANO-FIBER (CNFs)}

Fibrous carbon nano-materials, such as carbon Nano fibers (CNFs), have attracted a lot of attention because of their unique crystalline structure as well as excellent physical and chemical characteristics. Because of these characteristics, a variety of potential applications have been reported [108].The major processing route towards the CNFs has been the catalytic decomposition of molecules containing the carbon atoms such as hydrocarbons. Jia and Zhang [109] synthesized CNFs by CVD using acetylene $\left(\mathrm{C}_{2} \mathrm{H}_{2}\right)$ gas as the carbon precursor and the water-soluble salt from KI as the catalyst. Chemical vapor deposition can be applied without the need for an iron incorporation step, Carbon Nano fibers on activated carbons produced from agricultural waste, since the biomass already contains iron. This iron, present in the ash content of the ACs, acts as a "natural catalyst" and can catalyze the formation of CNFs from ethylene on biomass derived ACs [110]. Also platelet CNF was synthesized from carbon monoxide over an iron catalyst $[111,112]$. Romero et al. [113] prepared carbon nanofibers by the decomposition of $\mathrm{C}_{2} \mathrm{H}_{4}$ using different metal phase over $\mathrm{Y}$ zeolite. It was found that the metal phase had very plentiful effects on CNFs growth, including the extinction rate and the CNF production. Poly ethylene glycol can be used as the carbon source and $\mathrm{NiCl}_{2}$ as the catalytic for synthesis of carbon nano fibers by thermal decomposition from polymer and a catalyst. Heated this mixture at $400{ }^{\circ} \mathrm{C}$ and then increasing the temperature to $600-850{ }^{\circ} \mathrm{C}$ for the produce of carbon Nano fiber [114]. CNFs were synthesized by CVD method using ultra-fine $\mathrm{Fe}_{3} \mathrm{O}_{4}$ as the catalyst and $\mathrm{CO}$ as the carbon source [115]. Oil palm shell powdered activated carbon (PAC) was used as carbon resource for production. Carbon Nano fibers have been prepared from $\mathrm{C}_{2} \mathrm{H}_{2}$ by impregnation with nickel and using CVD in the presence of hydrogen gas. CNFs were synthesised directly on the surface of the impregnated oil palm shell [116]. High quality carbon Nano fibers were synthesized by CVD method using acetylene as carbon source and $\gamma$-alumina-supported iron as catalyst in a tubular quartz reactor 
[117]. Preparation of porous carbon that exhibits nano structure with high surface area and large-level nitrogen has bennalso investigated by doping polypyrrole (PPy). Nanofiber webs with a high $\mathrm{N}$ content $(\sim$ $16 \mathrm{wt} \%)$ were selected as precursor, and $\mathrm{KOH}$ served as an activation reagent to forms porous structure. Benefiting from the unique porous nano structure and high-level $\mathrm{N}$ doping, the CNF exhibit excellent rate capability [118]. Carbon nanotube and carbon nanofiber can be generated by an alumina template membrane with $\mathrm{Ni}$ catalyst using CVD method. Using ethylene used as carbon source, the carbon tubes can be converted into carbon nano fibers with increasing the deposition time [119].

\section{ACTIVATED CARBON APPLICATIONS}

Activated carbon is the most widely used adsorbent for removal of heavy metals, dyes, organic compounds, other pollutants in waste water treatment [120],petroleum industries [121], purification and separation of gaseous and liquid phase mixtures [108, 109], catalysis [122, 123],super capacitors [43], energy storage [124], fuel cells batteries [125], nuclear power stations [126], electric double layer capacitors [127], pharmaceutical industries [128], and hydrometallurgy [129, 130]. Gold can be separated from liquors by activated carbon as sorbent [131]. Activated carbon is used in purposes of deodorization and decolourization in food industries [132]. Abrasion resistance and hardness properties are very important factor for the AC. If an application needs to frequent back-washing such as air conditioning, AC will be a good choice for this purpose, due to ability to air filtration [133].

\subsection{CAPACITY OF AC FOR REMOVING POLLUTANT}

Properties of $\mathrm{AC}$ are determined by its pore volume, surface area and presence of different functional groups such as aldehydes, ketones, phenols, lactones, anhydrides, quinones, hydroquinone and carboxyl [134]. However, removal of pollutant by adsorption from liquid needs large surface area [39].

\section{APPLICATION OF NANO-CARBON}

Presence of heavy metals like $\mathrm{Cd}, \mathrm{Pb}, \mathrm{Ni}$, $\mathrm{Hg}$ and Cause major pollution problems in water stream. Carbon nano-tubes (CNTs) can be used as adsorbent of heavy metals contaminated from waste steam. Elimination of Nickel by adsorption method can be performed using multiwall carbon nanotubes (MWCNTs). Among the different parameters that may affect on adsorption process, $\mathrm{Ni}$ (II) adsorption onto MWCNTs was found to depend on $\mathrm{pH}$ and oxidized MWCNT concentration [107]. The sorption capacities of metal ions by oxidized CNTs are better than raw CNTs due to oxidation process upgrade. Their dispersivity and increases amount of oxygencontaining functional groups like $-\mathrm{COOH}$, $-\mathrm{OH}$, or $-\mathrm{CO}$ on the surface site of CNTs are important properties [135-137]. The carbon nano tube sheets were then oxidized with concentrated acid for elimination of some heavy metal ions from pollutant water. The demonstrated adsorption capacity of the CNT sheets increases significantly after oxidation process. Also, the adsorption capacity of the CNT increasing with increases the initial salts concentration [138]. The functional groups present on $\mathrm{AC}$ surface cause a rise in negative charge on carbon surface and the oxygen atoms in functional groups donate single pair of electrons to metal ions, so increasing their 
cation exchange capacity. MWCNTs have good adsorption capacity for chromium ions. The adsorption capability is increased by increasing the sedition speed and it is $\mathrm{pH}$ dependent. Our results demonstrate that the MWCNTs/Nano-iron oxide magnetic composites, whose surface area is large, are very promising materials as adsorbent for pollutant in water with good performances [139]. The properties of CNTs such as purity, structure and nature of the surface could be highly improved by acid treatment which made CNTs become more hydrophilic and convenient for adsorption of low molecular weight and relatively polar tri halo methane (THM). Molecules such as $\mathrm{CHCl}_{3}, \mathrm{CHBr}_{3}, \mathrm{CHBrCl}_{2}, \mathrm{CHBr}_{2} \mathrm{Cl}$, and $\mathrm{CHCl}_{3}$, are the most suitable adsorbed onto CNTs [140].Multi-walled carbon nanotubes (CNTs) were thermally treated used as adsorbents to remove some natural organic matter from aqueous solutions. The amount of adsorbed natural organic matter onto CNTs increased with increasing an initial concentration of contaminants, but decreased with a rise in solution $\mathrm{pH}$ [141]. Multi-walled carbon nanotubes (MWNT) and single-walled carbon nanotubes (SWNT) are efficient adsorbents for removal of tetracycline from contaminated aqueous solutions. The results of the present work tick that the adsorption selectivity and efficiency has evolved through specific molecular-level interactions between organic contaminants and carbon nanotubes [142]. Liao and Gao used multi-walled carbon nanotubes as efficient adsorbents for adsorbed resorcinol and other phenolic derivatives from water. They showed that multi-walled carbon nanotubes have ideal performance for adsorption of phenolic derivatives, which can be utilize not only in the environmental protection but also in many scientific fields such as catalyst support and chemical sensors. The potential of adsorption process depended on contact time, $\mathrm{pH}$ range, Acid-treated MWCNTs, hydroxyl and its location in meta-position on aromatic ring [143].

\section{REFERENCES}

[1] Nassar, N. N. (2010). Kinetics, mechanistic, equilibrium, and thermodynamic studies on the adsorption of acid red dye from wastewater by $\gamma$-Fe2O3 nanoadsorbents. Separation Science and Technology, 45(8), 1092-1103.

[2] Ghosh, M., \& Singh, S. (2005). A review on phytoremediation of heavy metals and utilization of it's by products. Asian J Energy Environ, 6(4), 18.

[3] Yagub, M. T., Sen, T. K., Afroze, S., \&Ang, H. M. (2014). Dye and its removal from aqueous solution by adsorption: a review. Advances in colloid and interface science, 209, 172-184.

[4] Abdel Ghafar, H. H., Ali, G. A., Fouad, O. A., \&Makhlouf, S. A. (2015). Enhancement of adsorption efficiency of methylene blue on $\mathrm{Co} 3 \mathrm{O} 4 / \mathrm{SiO} 2$ nanocomposite. Desalination and Water Treatment, 53(11), 2980-2989.

[5] Gupta, V. K., Moradi, O., Tyagi, I., Agarwal, S., Sadegh, H., Shahryari-Ghoshekandi, R., ... \&Garshasbi, A. (2016). Study on the removal of heavy metal ions from industry waste by carbon nanotubes: effect of the surface modification: a review. Critical Reviews in Environmental Science and Technology, 46(2), 93-118.

[6] Ghaedi, M., Zeinali, N., Ghaedi, A. M., Teimuori, M., \&Tashkhourian, J. (2014). Artificial neural network-genetic algorithm based optimization for the adsorption of methylene blue and brilliant green from aqueous solution by graphite oxide nanoparticle. SpectrochimicaActa Part A: Molecular and Biomolecular Spectroscopy, 125, 264-277.

[7] Kovalova, L., Siegrist, H., Von Gunten, U., Eugster, J., Hagenbuch, M., Wittmer, A., ...\&McArdell, C. S. (2013). Elimination of micropollutants during post-treatment of hospital wastewater with powdered activated 
carbon, ozone, and UV. Environmental science \& technology, 47(14), 7899-7908.

[8] White, R. J., Luque, R., Budarin, V. L., Clark, J. H., \&Macquarrie, D. J. (2009). Supported metal nanoparticles on porous materials.Methods and applications. Chemical Society Reviews, 38(2), 481-494.

[9] Atkinson, J. D., Fortunato, M. E., Dastgheib, S. A., Rostam-Abadi, M., Rood, M. J., \&Suslick, K. S. (2011). Synthesis and characterization of iron-impregnated porous carbon spheres prepared by ultrasonic spray pyrolysis. Carbon, 49(2), 587-598.

[10] Chen, X., Kierzek, K., Jiang, Z., Chen, H., Tang, T., Wojtoniszak, M., ...\&BorowiakPalen, E. (2011). Synthesis, growth mechanism, and electrochemical properties of hollow mesoporous carbon spheres with controlled diameter. The Journal of Physical Chemistry C, 115(36), 17717-17724.

[11] Matos, J., Atienzar, P., García, H., \& Hernández-Garrido, J. C. (2013). Nanocrystalline carbon-TiO 2 hybrid hollow spheres as possible electrodes for solar cells. Carbon, 53, 169-181.

[12] Huang, F. C., Lee, C. K., Han, Y. L., Chao, W. C., \& Chao, H. P. (2014). Preparation of activated carbon using micro-nano carbon spheres through chemical activation. Journal of the Taiwan Institute of Chemical Engineers, 45(5), 2805-2812.

[13] Ali, G. A., Manaf, S. A. B. A., Kumar, A., Chong, K. F., \&Hegde, G. (2014). High performance supercapacitor using catalysis free porous carbon nanoparticles. Journal of Physics D: Applied Physics, 47(49), 495307.

[14] Ali, G. A., Manaf, S. A. A., Divyashree, A., Chong, K. F., \&Hegde, G. (2016). Superior supercapacitive performance in porous nanocarbons. Journal of Energy Chemistry, 25(4), 734-739.

[15] Wyman, C. E. (1994). Alternative fuels from biomass and their impact on carbon dioxide accumulation. Applied biochemistry and biotechnology, 45(1), 897-915.

[16] Van Wyk, J. P. (2001). Biotechnology and the utilization of biowaste as a resource for bioproduct development. TRENDS in Biotechnology, 19(5), 172-177.
[17] Habila, M. A., ALOthman, Z. A., Al-Tamrah, S. A., Ghafar, A. A., \&Soylak, M. (2015). Activated carbon from waste as an efficient adsorbent for malathion for detection and removal purposes. Journal of Industrial and Engineering Chemistry, 32, 336-344.

[18] Lei, Z., Zhao, M., Dang, L., An, L., Lu, M., Lo, A. Y., ... \& Liu, S. B. (2009). Structural evolution and electrocatalytic application of nitrogen-doped carbon shells synthesized by pyrolysis of nearmonodispersepolyanilinenanospheres. Journal of Materials Chemistry, 19(33), 5985-5995.

[19] Stein, A., Wang, Z., \&Fierke, M. A. (2009). Functionalization of porous carbon materials with designed pore architecture. Advanced Materials, 21(3), 265-293.

[20] Li, F., Qian, Q., Yan, F., \& Yuan, G. (2006). Nitrogen-doped porous carbon microspherules as supports for preparing monodisperse nickel nanoparticles. Carbon, 44(1), 128-132.

[21] Bazuła, P. A., Lu, A. H., Nitz, J. J., \&Schüth, F. (2008). Surface and pore structure modification of ordered mesoporous carbons via a chemical oxidation approach. Microporous and Mesoporous Materials, 108(1), 266-275.

[22] Lázaro, M. J., Calvillo, L., Bordejé, E. G., Moliner, R., Juan, R., \& Ruiz, C. R. (2007). Functionalization of ordered mesoporous carbons synthesized with SBA-15 silica as template. Microporous and mesoporous materials, 103(1), 158-165.

[23] Li, J., Ng, D. H., Song, P., Kong, C., Song, Y., \& Yang, P. (2015). Preparation and characterization of high-surface-area activated carbon fibers from silkworm cocoon waste for congo red adsorption. Biomass and Bioenergy, 75, 189-200.

[24] González, J. F., Román, S., Encinar, J. M., \&Martínez, G. (2009). Pyrolysis of various biomass residues and char utilization for the production of activated carbons. Journal of Analytical and Applied Pyrolysis, 85(1), 134141.

[25] Wang, Y. Y., Huang, Q., Xian, Q. M., \& Sun, C. (2012). Preparation of Activated Carbon Fiber Supported Nanoscale $\mathrm{Fe} 0$ for Simultaneous Adsorption and Dechlorination of Chloroform in Water. In Advanced Materials 
Research(Vol. 399, pp. 1386-1391). Trans Tech Publications.

[26] Elwakeel, K. Z. (2010). Removal of Cr (VI) from alkaline aqueous solutions using chemically modified magnetic chitosan resins. Desalination, 250(1), 105-112.

[27] Daifullah, A. A. M., Yakout, S. M., \&Elreefy, S. A. (2007). Adsorption of fluoride in aqueous solutions using $\mathrm{KMnO}$ 4-modified activated carbon derived from steam pyrolysis of rice straw. Journal of Hazardous Materials, 147(1), 633-643.

[28] Cimino, G., Cappello, R. M., Caristi, C., \&Toscano, G. (2005). Characterization of carbons from olive cake by sorption of wastewater pollutants. Chemosphere, 61(7), 947-955.

[29] Yahya, M. A., Al-Qodah, Z., \&Ngah, C. Z. (2015). Agricultural bio-waste materials as potential sustainable precursors used for activated carbon production: a review. Renewable and Sustainable Energy Reviews, 46, 218-235.

[30] Williams, P. T., \& Reed, A. R. (2006). Development of activated carbon pore structure via physical and chemical activation of biomass fibre waste. Biomass and Bioenergy, 30(2), 144152.

[31] Williams, P. T., \& Reed, A. R. (2004). High grade activated carbon matting derived from the chemical activation and pyrolysis of natural fibre textile waste. Journal of analytical and applied pyrolysis, 71(2), 971-986.

[32] Williams, P. T., \& Reed, A. R. (2003). Preformed activated carbon matting derived from the pyrolysis of biomass natural fibre textile waste. Journal of Analytical and Applied Pyrolysis, 70(2), 563-577.

[33] Daud, W. M. A. W., \& Ali, W. S. W. (2004). Comparison on pore development of activated carbon produced from palm shell and coconut shell. Bioresource Technology, 93(1), 63-69.

[34] Laine, J., \&Yunes, S. (1992). Effect of the preparation method on the pore size distribution of activated carbon from coconut shell. Carbon, 30(4), 601-604.

[35] Ali, I. (2010). The quest for active carbon adsorbent substitutes: inexpensive adsorbents for toxic metal ions removal from wastewater. Separation \& Purification Reviews, 39(3-4), 95-171.

[36] Ahmadpour, A., \& Do, D. D. (1997). The preparation of activated carbon from macadamia nutshell by chemical activation. Carbon, 35(12), 1723-1732.

[37] Houache, O., Al-Maamari, R., Al-Rashidi, B., \&Jibril, B. (2008). Study of date palm stem as raw material in preparation of activated carbon. J Eng Res, 5(1), 47-54.

[38] Girgis, B. S., Yunis, S. S., \&Soliman, A. M. (2002). Characteristics of activated carbon from peanut hulls in relation to conditions of preparation. Materials Letters, 57(1), 164-172.

[39] Abechi, S. E., Gimba, C. E., Uzairu, A., \&Dallatu, Y. A. (2013). Preparation and characterization of activated carbon from palm kernel shell by chemical activation. Res. J. Chem. Sci, 3(7), 54-61.

[40] Cagnon, B., Py, X., Guillot, A., Stoeckli, F., \&Chambat, G. (2009). Contributions of hemicellulose, cellulose and lignin to the mass and the porous properties of chars and steam activated carbons from various lignocellulosic precursors. Bioresource Technology, 100(1), 292-298.

[41] Demiral, H., Demiral, I., Tumsek, F., \&Karabacakoglu, B. (2008). Pore structure of activated carbon prepared from hazelnut bagasse by chemical activation. Surface and Interface Analysis, 40(3), 616-619.

[42] Gupta, H., \&Gogate, P. R. (2016). Intensified removal of copper from waste water using activated watermelon based biosorbent in the presence of ultrasound. Ultrasonicssonochemistry, 30, 113122.

[43] Abioye, A. M., \&Ani, F. N. (2015). Recent development in the production of activated carbon electrodes from agricultural waste biomass for supercapacitors: a review. Renewable and Sustainable Energy Reviews, 52, 1282-1293.

[44] Ahmad Khan, N., Ibrahim, S., \&Subramaniam, P. (2004). Elimation of Heavy Metals from Wastewater Using Agricultural Wastes as Adsorbents. Malaysian Journal of Science, 23(1). 
[45] Park, D., Yun, Y. S., \& Park, J. M. (2010). The past, present, and future trends of biosorption. Biotechnology and Bioprocess Engineering, 15(1), 86-102.

[46] Nor, N. M., Lau, L. C., Lee, K. T., \& Mohamed, A. R. (2013). Synthesis of activated carbon from lignocellulosic biomass and its applications in air pollution control-a review. Journal of Environmental Chemical Engineering, 1(4), 658-666.

[47] Ould-Idriss, A., Stitou, M., Cuerda-Correa, E. M., Fernández-González, C., Macías-García, A., Alexandre-Franco, M. F., \& Gómez-Serrano, V. (2011). Preparation of activated carbons from olive-tree wood revisited. II. Physical activation with air. Fuel processing technology, 92(2), 266-270.

[48] Şahin, Ö.,\&Saka, C. (2013). Preparation and characterization of activated carbon from acorn shell by physical activation with $\mathrm{H} 2 \mathrm{O}-\mathrm{CO} 2$ in two-step pretreatment. Bioresource technology, 136, 163-168.

[49] Bouchelta, C., Medjram, M. S., Bertrand, O., \&Bellat, J. P. (2008). Preparation and characterization of activated carbon from date stones by physical activation with steam. Journal of Analytical and Applied Pyrolysis, 82(1), 70-77.

[50] Gergova, K., Petrov, N., Butuzova, L., Minkova, V., \&Isaeva, L. (1993). Evolution of the active surface of carbons produced from various raw materials by steam pyrolysis/activation. Journal of chemical technology and biotechnology, 58(4), 321-330.

[51] Matos, J., Nahas, C., Rojas, L., \& Rosales, M. (2011). Synthesis and characterization of activated carbon from sawdust of Algarroba wood. 1. Physical activation and pyrolysis. Journal of hazardous materials, 196, 360-369.

[52] Nowicki, P., Supłat, M., Przepiórski, J., \&Pietrzak, R. (2012). NO 2 removal on adsorbents obtained by pyrolysis and physical activation of corrugated cardboard. Chemical engineering journal, 195, 7-14.

[53] Gao, Y., Xu, S., Yue, Q., Wu, Y., \&Gao, B. (2016). Chemical preparation of crab shellbased activated carbon with superior adsorption performance for dye removal from wastewater. Journal of the Taiwan Institute of Chemical Engineers, 61, 327-335.

[54] Inal, I. I. G., Holmes, S. M., Banford, A., \&Aktas, Z. (2015). The performance of supercapacitor electrodes developed from chemically activated carbon produced from waste tea. Applied Surface Science, 357, 696703.

[55] Ioannidou, O., \&Zabaniotou, A. (2007). Agricultural residues as precursors for activated carbon production-a review. Renewable and Sustainable Energy Reviews, 11(9), 1966-2005.

[56] Uçar, S., Erdem, M., Tay, T., \&Karagöz, S. (2009). Preparation and characterization of activated carbon produced from pomegranate seeds by $\mathrm{ZnCl} 2$ activation. Applied Surface Science, 255(21), 8890-8896.

[57] Rodriguez-Reinoso, F., \& Molina-Sabio, M. (1992). Activated carbons from lignocellulosic materials by chemical and/or physical activation: an overview. Carbon, 30(7), 1111-1118.

[58] Sudaryanto, Y., Hartono, S. B., Irawaty, W., Hindarso, H., \&Ismadji, S. (2006). High surface area activated carbon prepared from cassava peel by chemical activation. Bioresource Technology, 97(5), 734-739.

[59] Shehzad, A., Bashir, M. J., Sethupathi, S., \& Lim, J. W. (2015). An overview of heavily polluted landfill leachate treatment using food waste as an alternative and renewable source of activated carbon. Process Safety and Environmental Protection, 98, 309-318.

[60] Laine, J., \&Calafat, A. (1989). Preparation and characterization of activated carbons from coconut shell impregnated with phosphoric acid. Carbon, 27(2), 191-195.

[61] Adinata, D., Daud, W. M. A. W., \&Aroua, M. K. (2007). Preparation and characterization of activated carbon from palm shell by chemical activation with $\mathrm{K} 2 \mathrm{CO}$ 3. Bioresource Technology, 98(1), 145-149.

[62] Bhadusha, N., \&Ananthabaskaran, T. (2011). Adsorptive removal of methylene blue onto $\mathrm{ZnCl} 2$ activated carbon from wood apple outer shell: kinetics and equilibrium studies. Journal of Chemistry, 8(4), 1696-1707.

[63] Zhang, Y. J., Xing, Z. J., Duan, Z. K., Li, M., \& Wang, Y. (2014). Effects of steam activation 
on the pore structure and surface chemistry of activated carbon derived from bamboo waste. Applied Surface Science, 315, 279-286.

[64] Valix, M., Cheung, W. H., \& McKay, G. (2004). Preparation of activated carbon using low temperature carbonisation and physical activation of high ash raw bagasse for acid dye adsorption. Chemosphere, 56(5), 493-501.

[65] Darmstadt, H., Garcia-Perez, M., Chaala, A., Cao, N. Z., \& Roy, C. (2001). Co-pyrolysis under vacuum of sugar cane bagasse and petroleum residue: properties of the char and activated char products. Carbon, 39(6), 815825.

[66] Sekirifa, M. L., Hadj-Mahammed, M., Pallier, S., Baameur, L., Richard, D., \& Al-Dujaili, A. H. (2013). Preparation and characterization of an activated carbon from a date stones variety by physical activation with carbon dioxide. Journal of Analytical and Applied Pyrolysis, 99, 155-160.

[67] Sumathi, S., Bhatia, S., Lee, K. T., \& Mohamed, A. R. (2009). Optimization of microporous palm shell activated carbon production for flue gas desulphurization: Experimental and statistical studies. Bioresource technology, 100(4), 1614-1621.

[68] Tseng, H. H., \& Wey, M. Y. (2004). Study of SO 2 adsorption and thermal regeneration over activated carbon-supported copper oxide catalysts. Carbon, 42(11), 2269-2278.

[69] Brazhnyk, D. V., Zaitsev, Y. P., Bacherikova, I. V., Zazhigalov, V. A., Stoch, J., \&Kowal, A. (2007). Oxidation of H 2 S on activated carbon KAU and influence of the surface state. Applied Catalysis B: Environmental, 70(1), 557-566.

[70] Huang, Y. P., Hou, C. H., Hsi, H. C., \& Wu, J. W. (2015). Optimization of highly microporous activated carbon preparation from Moso bamboo using central composite design approach. Journal of the Taiwan Institute of Chemical Engineers, 50, 266-275.

[71] Elkady, M. F., Hussein, M. M., \&Salama, M. M. (2015). Synthesis and characterization of nano-activated carbon from el maghara coal, Sinai, Egypt to be utilized for wastewater Purification. American Journal of Applied Chemistry, 3(3), 1-7.
[72] Sayğıll, H., Güzel, F., \&Önal, Y. (2015). Conversion of grape industrial processing waste to activated carbon sorbent and its performance in cationic and anionic dyes adsorption. Journal of Cleaner Production, 93, 84-93.

[73] Sayğıll, H., \&Güzel, F. (2016). High surface area mesoporous activated carbon from tomato processing solid waste by zinc chloride activation: process optimization, characterization and dyes adsorption. Journal of Cleaner Production, 113, 995-1004.

[74] Saleh, T. A., \&Danmaliki, G. I. (2016). Influence of acidic and basic treatments of activated carbon derived from waste rubber tires on adsorptive desulfurization of thiophenes. Journal of the Taiwan Institute of Chemical Engineers, 60, 460-468.

[75] Macías-Pérez, M. C., Bueno-López, A., LilloRódenas, M. A., de Lecea, C. S. M., \& LinaresSolano, A. (2007). SO 2 retention on $\mathrm{CaO} /$ activated carbon sorbents. Part I: importance of calcium loading and dispersion. Fuel, 86(5), 677-683.

[76] Liu, D., Zhang, W., Lin, H., Li, Y., Lu, H., \& Wang, Y. (2016). A green technology for the preparation of high capacitance rice husk-based activated carbon. Journal of Cleaner Production, 112, 1190-1198.

[77] Li, W., Tan, S., Shi, Y., \& Li, S. (2015). Utilization of sargassum based activated carbon as a potential waste derived catalyst for low temperature selective catalytic reduction of nitric oxides. Fuel, 160, 35-42.

[78] Nowicki, P., Wachowska, H., \&Pietrzak, R. (2010). Active carbons prepared by chemical activation of plum stones and their application in removal of NO 2. Journal of hazardous materials, 181(1), 1088-1094.

[79] Savova, D., Apak, E., Ekinci, E., Yardim, F., Petrov, N., Budinova, T., ...\&Minkova, V. (2001). Biomass conversion to carbon adsorbents and gas. Biomass and Bioenergy, 21(2), 133-142.

[80] Abbaszadeh, S., Alwi, S. R. W., Webb, C., Ghasemi, N., \&Muhamad, I. I. (2016). Treatment of lead-contaminated water using activated carbon adsorbent from locally available papaya peel biowaste. Journal of Cleaner Production, 118, 210-222. 
[81] Cruz, G., Pirilä, M., Huuhtanen, M., Carrión, L., Alvarenga, E., \&Keiski, R. L. (2012). Production of activated carbon from cocoa (Theobroma cacao) pod husk. J Civil Environ Eng, 2(2), 1-6.

[82] Rufford, T. E., Hulicova-Jurcakova, D., Khosla, K., Zhu, Z., \& Lu, G. Q. (2010). Microstructure and electrochemical doublelayer capacitance of carbon electrodes prepared by zinc chloride activation of sugar cane bagasse. Journal of Power Sources, 195(3), 912918.

[83] Azevedo DC, Araujo JC, Bastos-Neto M, Torres AE, Jaguaribe EF, Cavalcante CL. Microporous activated carbon prepared from coconut shells using chemical activation with zinc chloride. Microporous and Mesoporous Materials. 2007 Mar 23;100(1):361-4.

[84] Zhang, J., Gong, L., Sun, K., Jiang, J., \& Zhang, X. (2012). Preparation of activated carbon from waste Camellia oleifera shell for supercapacitor application. Journal of Solid State Electrochemistry, 16(6), 2179-2186.

[85] Li X, Xing W, Zhuo S, Zhou J, Li F, Qiao SZ, Lu GQ. Preparation of capacitor's electrode from sunflower seed shell.Bioresource technology. 2011 Jan 31;102(2):1118-23.

[86] Zhang, Z., Luo, X., Liu, Y., Zhou, P., Ma, G., Lei, Z., \& Lei, L. (2015). A low cost and highly efficient adsorbent (activated carbon) prepared from waste potato residue. Journal of the Taiwan Institute of Chemical Engineers, 49, 206-211.

[87] Hayashi, J. I., Kazehaya, A., Muroyama, K., \& Watkinson, A. P. (2000). Preparation of activated carbon from lignin by chemical activation. Carbon, 38(13), 1873-1878.

[88] Pierard, N., Fonseca, A., Colomer, J. F., Bossuot, C., Benoit, J. M., Van Tendeloo, G., ...\& Nagy, J. B. (2004). Ball milling effect on the structure of single-wall carbon nanotubes. Carbon, 42(8), 1691-1697.

[89] [89] Chen, X. H., Yang, H. S., Wu, G. T., Wang, M., Deng, F. M., Zhang, X. B., ...\& Li, W. Z. (2000). Generation of curved or closedshell carbon nanostructures by ball-milling of graphite. Journal of crystal growth, 218(1), 5761.
[90] Casati, R., Fiocchi, J., Fabrizi, A., Lecis, N., Bonollo, F., \&Vedani, M. (2017). Effect of ball milling on the ageing response of $\mathrm{Al} 2618$ composites reinforced with $\mathrm{SiC}$ and oxide nanoparticles. Journal of Alloys and Compounds, 693, 909-920.

[91] Manaf, S. A. A., Roy, P., Sharma, K. V., Ngaini, Z., Malgras, V., Aldalbahi, A., ... \&Hegde, G. (2015). Catalyst-free synthesis of carbon nanospheres for potential biomedical applications: waste to wealth approach. RSC Advances, 5(31), 24528-24533.

[92] Shuo, Z., WANG, C. Y., CHEN, M. M., SHI, Z. Q., \& Na, L. (2010). Preparation of carbon spheres from potato starch and its stabilization mechanism. New carbon materials, 25(6), 438443.

[93] Yan, Y., Yang, H., Zhang, F., Tu, B., \& Zhao, D. (2007). Low-temperature solution synthesis of carbon nanoparticles, onions and nanoropes by the assembly of aromatic molecules. Carbon, 45(11), 2209-2216.

[94] Yuan, D., Chen, J., Zeng, J., \& Tan, S. (2008). Preparation of monodisperse carbon nanospheres for electrochemical capacitors. Electrochemistry communications, 10(7), 1067-1070.

[95] Wang, X., Wang, H., Dai, Q., Li, Q., Yang, J., Zhang, A., \& Yan, Z. (2009). Preparation of novel porous carbon spheres from corn starch. Colloids and Surfaces A: Physicochemical and Engineering Aspects, 346(1), 213-215.

[96] Jin, Y. Z., Gao, C., Hsu, W. K., Zhu, Y., Huczko, A., Bystrzejewski, M., ...\& Walton, D. R. (2005). Large-scale synthesis and characterization of carbon spheres prepared by direct pyrolysis of hydrocarbons. Carbon, 43(9), 1944-1953.

[97] Odom, T. W., Huang, J. L., Kim, P., \&Lieber, C. M. (1998). Atomic structure and electronic properties of single-walled carbon nanotubes. Nature, 391(6662), 62-64.

[98] Balkanski, M. (2000). Physical Properties of Carbon Nanotubes, Edited by R. Saito, G. Dresselhaus and MS Dresselhaus, Imperial College Press, London, 1998.

[99] Ahn, J. H., Shin, H. S., Kim, Y. J., \& Chung, H. (2007). Structural modification of carbon 
nanotubes by various ball milling. Journal of alloys and compounds, 434, 428-432.

[100] Ago, H., Nakamura, K., Imamura, S., \& Tsuji, M. (2004). Growth of double-wall carbon nanotubes with diameter-controlled iron oxide nanoparticles supported on $\mathrm{MgO}$. Chemical Physics Letters, 391(4), 308-313.

[101] Zhu, J., Jia, J., Kwong, F. L., Ng, D. H. L., \&Tjong, S. C. (2012).Synthesis of multiwalled carbon nanotubes from bamboo charcoal and the roles of minerals on their growth. biomass and bioenergy, 36, 12-19.

[102] Chen, Y., Conway, M. J., Gerald, J. F., Williams, J. S., \&Chadderton, L. T. (2004).The nucleation and growth of carbon nanotubes in a mechano-thermal process. Carbon, 42(8), 1543-1548.

[103] Su, D. S. (2009).The use of natural materials in nanocarbon synthesis. ChemSusChem, 2(11), 1009-1020.

[104] Endo, M., Takeuchi, K., Kim, Y. A., Park, K. C., Ichiki, T., Hayashi, T., ...\&Dresselhaus, M. S. (2008). Simple synthesis of multiwalled carbon nanotubes from natural resources. ChemSusChem, 1(10), 820-822.

[105]Xu, Z. X., Lin, J. D., Roy, V. A. L., Ou, Y., \& Liao, D. W. (2005). Catalytic synthesis of carbon nanotubes and carbon spheres using Kaolin supported catalyst. Materials Science and Engineering: B, 123(2), 102-106.

[106] Sun, L., Yan, C., Chen, Y., Wang, H., \& Wang, Q. (2012).Preparation of amorphous carbon nanotubes using attapulgite as template and furfuryl alcohol as carbon source. Journal of Non-Crystalline Solids, 358(18), 2723-2726.

[107] Chen, C., \& Wang, X. (2006). Adsorption of $\mathrm{Ni}$ (II) from aqueous solution using oxidized multiwall carbon nanotubes. Industrial \& Engineering Chemistry Research, 45(26), 91449149.

[108] Nieto-Márquez, A., Toledano, D., Lazo, J. C., Romero, A., \&Valverde, J. L. (2010). Carbon nanospheres as novel support in the nickel catalyzed gas phase hydrogenation of butyronitrile. Applied Catalysis A: General, 373(1), 192-200.

[109] Jia, M., \& Zhang, Y. (2009). Study on the synthesis of carbon fibers and CNF using potassium iodide catalyst. Materials Letters, 63(24), 2111-2114.

[110] Chen, X. W., Timpe, O., Hamid, S. B., Schlögl, R., \& Su, D. S. (2009). Direct synthesis of carbon nanofibers on modified biomass-derived activated carbon. Carbon, 47(1), 340-343.

[111] Best, R. J., \& Russell, W. W. (1954).Nickel, Copper and Some of their Alloys as Catalysts for Ethylene Hydrogenation1. Journal of the American Chemical Society, 76(3), 838-842.

[112] Sinfelt, J. H., Carter, J., \& Yates, D. J. C. (1972).Catalytic hydrogenolysis and dehydrogenation over copper-nickel alloys. Journal of Catalysis, 24(2), 283-296.

[113] Romero, A., Garrido, A., Nieto-Márquez, A., Sánchez, P., de Lucas, A., \&Valverde, J. L. (2008). Synthesis and structural characteristics of highly graphitized carbon nanofibers produced from the catalytic decomposition of ethylene: Influence of the active metal $(\mathrm{Co}, \mathrm{Ni}$, $\mathrm{Fe}$ ) and the zeolite type support. Microporous and Mesoporous Materials, 110(2), 318-329.

[114] Huang, C. W., Wu, H. C., Lin, W. H., \& Li, Y. Y. (2009).Temperature effect on the formation of catalysts for growth of carbon nanofibers. Carbon, 47(3), 795-803.

[115] Zhou, Q., Li, P., Wang, X., Zhou, X., Yang, D., \& Chen, D. (2011).Preparation of CNFsupported Pt catalysts for hydrogen evolution from decalin. Materials Chemistry and Physics, 126(1), 41-45.

[116] Mamun, A. A., Ahmed, Y. M., Muyibi, S. A., Al-Khatib, M. F. R., Jameel, A. T., \&AlSaadi, M. A. (2016). Synthesis of carbon nanofibers on impregnated powdered activated carbon as cheap substrate. Arabian Journal of Chemistry, 9(4), 532-536.

[117] Taboada, C. D., Batista, J., Pintar, A., \&Levec, J. (2009).Preparation, characterization and catalytic properties of carbon nanofibersupported $\mathrm{Pt}, \mathrm{Pd}, \mathrm{Ru}$ monometallic particles in aqueous-phase reactions. Applied Catalysis B: Environmental, 89(3), 375-382.

[118] Qie, L., Chen, W. M., Wang, Z. H., Shao, Q. G., Li, X., Yuan, L. X., ... \& Huang, Y. H. (2012). Nitrogen-doped porous carbon nanofiber webs as anodes for lithium ion batteries with a superhigh capacity and rate 
capability. Advanced materials, 24(15), 20472050.

[119] Che, G., Lakshmi, B. B., Martin, C. R., Fisher, E. R., \&Ruoff, R. S. (1998). Chemical vapor deposition based synthesis of carbon nanotubes and nanofibers using a template method. Chemistry of Materials, 10(1), 260267.

[120] Kyzas, G. Z., \&Kostoglou, M. (2014). Green adsorbents for wastewaters: a critical review. Materials, 7(1), 333-364.

[121] Tawalbeh, M., Allawzi, M. A., \&Kandah, M. I. (2005).Production of Activated Carbon from Jojoba Seed Residue by Chemical Activation Residue Using a Static Bed Reactor. Journal of Applied Sciences, 5, 482-487.

[122] Lee, J., Kim, J., \&Hyeon, T. (2006).Recent progress in the synthesis of porous carbon materials. Advanced Materials, 18(16), 20732094.

[123] Azargohar, R., \& Dalai, A. K. (2006).Biochar as a precursor of activated carbon.In TwentySeventh Symposium on Biotechnology for Fuels and Chemicals (pp. 762-773). Humana Press.

[124] Kawano, T., Kubota, M., Onyango, M. S., Watanabe, F., \& Matsuda, H. (2008).Preparation of activated carbon from petroleum coke by $\mathrm{KOH}$ chemical activation for adsorption heat pump. Applied thermal engineering, 28(8), 865-871.

[125] Shah, J., Jan, M. R., Mabood, F., \&Shahid, M. (2006).Conversion of waste tyres into carbon black and their utilization as adsorbent. Journal of the Chinese Chemical Society, 53(5), 10851089.

[126] Zabaniotou, A. A., \& Stavropoulos, G. (2003).Pyrolysis of used automobile tires and residual char utilization. Journal of Analytical and Applied Pyrolysis, 70(2), 711-722.

[127] Kubota, M., Hata, A., \& Matsuda, H. (2009).Preparation of activated carbon from phenolic resin by $\mathrm{KOH}$ chemical activation under microwave heating. Carbon, 47(12), 2805-2811.

[128] Subha, R., \&Namasivayam, C. (2009). Zinc chloride activated coir pith carbon as low cost adsorbent for removal of 2, 4-dichlorophenol: Equilibrium and kinetic studies.
[129] McDougall, G. J. (1991).The physical nature and manufacture of activated carbon. Journal of the Southern African Institute of Mining and Metallurgy, 91(4), 109-120.

[130] Sun, K., Jiang, J. C., \& Jun-ming, X. (2009). Chemical regeneration of exhausted granular activated carbon used in citric acid fermentation solution decoloration. Iranian Journal of Chemistry and Chemical Engineering (IJCCE), 28(4), 79-83.

[131] Qureshi, K., Bhatti, I., Kazi, R., \& Ansari, A. K. (2008). Physical and chemical analysis of activated carbon prepared from sugarcane bagasse and use for sugar decolorisation. International Journal of Chemical and Biomolecular Engineering, 1(3), 145-149.

[132] Sahu, J. N., Acharya, J., \&Meikap, B. C. (2010). Optimization of production conditions for activated carbons from Tamarind wood by zinc chloride using response surface methodology. Bioresource technology, 101(6), 1974-1982.

[133] Yusufu, M. I., Ariahu, C. C., \&Igbabul, B. D. (2012). Production and characterization of activated carbon from selected local raw materials. African Journal of Pure and Applied Chemistry, 6(9), 123-131.

[134] Aygün, A., Yenisoy-Karakaş, S., \&Duman, I. (2003).Production of granular activated carbon from fruit stones and nutshells and evaluation of their physical, chemical and adsorption properties. Microporous and mesoporous materials, 66(2), 189-195.

[135] Li, Y. H., Wang, S., Wei, J., Zhang, X., Xu, C., Luan, Z., ...\& Wei, B. (2002). Lead adsorption on carbon nanotubes. Chemical Physics Letters, 357(3), 263-266.

[136] Shim, J. W., Park, S. J., \&Ryu, S. K. (2001).Effect of modification with HNO 3 and $\mathrm{NaOH}$ on metal adsorption by pitch-based activated carbon fibers. Carbon, 39(11), 16351642.

[137] Rao, G. P., Lu, C., \& Su, F. (2007). Sorption of divalent metal ions from aqueous solution by carbon nanotubes: a review. Separation and Purification Technology, 58(1), 224-231.

[138] Tofighy, M. A., \&Mohammadi, T. (2011).Adsorption of divalent heavy metal ions 
from water using carbon nanotube sheets. Journal of Hazardous Materials, 185(1), 140-147.

[139] Gupta, V. K., Agarwal, S., \&Saleh, T. A. (2011).Chromium removal by combining the magnetic properties of iron oxide with adsorption properties of carbon nanotubes. Water research, 45(6), 2207-2212.

[140] Lu, C., Chung, Y. L., \& Chang, K. F. (2005).Adsorption of trihalomethanes from water with carbon nanotubes. Water research, 39(6), 1183-1189.
[141] Lu, C., \& Su, F. (2007).Adsorption of natural organic matter by carbon nanotubes. Separation and Purification Technology, 58(1), 113-121.

[142] Ji, L., Chen, W., Duan, L., \& Zhu, D. (2009). Mechanisms for strong adsorption of tetracycline to carbon nanotubes: a comparative study using activated carbon and graphite as adsorbents. Environmental science \& technology, 43(7), 2322-2327.

[143] Liao, Q., Sun, J., \&Gao, L. (2008). The adsorption of resorcinol from water using multi-walled carbon nanotubes. Colloids and Surfaces A: Physicochemical and Engineering Aspects, 312(2), 160-165. 


\section{تحضير وتوصيف جزيئات الكربون المنشط النانومترية من المخلفات الزراعية لمعالجة مياه الصرف}

$$
\begin{aligned}
& \text { إبر اهيم إسماعيل إبر اهيم'، نبيلة شحاتة²، حمدي محمد فرغلي² جابر سيد عبد الغني2 } \\
& \text { 1 قسم الهنسة الكيميائية، كلية الهنسة، جامعة المنيا، المنيا، مصر. } \\
& \text { 2 كلية الدراسات العليا للعلوم المتقدمة، جامعة بني سويف، بني سويف، مصر. }
\end{aligned}
$$

الملخص:

يعد الصرف الصناعي أحد أخطر الملوثات التي تهدد البيئه لما يحتويه من عناصر سامة تؤثر علي الحياه المائيه، ويعد البحث عن طرق لاز اله هذه الملوثات ضروري للمحافظه علي صحة الانسان و الموارد المائيه، وقد استخدم الكربون المنشط على نطاق واسع كماده مازة للتخلص من هذه الملوثات وذلك لخصائصه الفريدة، وفي المقام الاول تعتمد خصائص الكربون الناتج على الماده الخام المستخدة، ولقد لقيت أبحاث تحضير وتوصيف الكربون المنشط من المو اد الغنية بالكربون مثل المخلفات الزراعيه اهتماما كبير ا من الباحثين، وفي هذا العرض تم مناقشة تحضير جزيئات الكربون المنشط النانومترية بالطرق الفيزيائية و الكيميائية بالاضافة الى توصيفها، كما تم مناقثه العوامل المؤثره على عمليه التنشيط و التفحم مثل (المواد الكيميائيه المستخدمه في التنشيط - درجة الحرارة) وتأثير ها على مساحة السطح وحجم المسام. أنشكال الكربون الناتجة ونطبيقاتها تم عرضها ايضا. كما تم عرض تأثير عمليه الطحن علي اشكال الكربون الناتجة. 